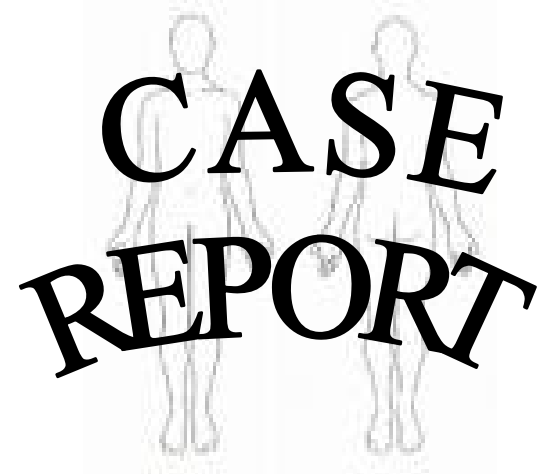

Introduction

Testicular cancer is a relatively rare cancer with an estimated 8,290 new cases diagnosed annually in the US. ${ }^{1}$ Germ cell carcinomas comprise the overwhelming majority $(98.9 \%)$ of adult testicular carcinomas. ${ }^{2}$ Ninety-five percent of germ cell tumors (GCTs) occur in the gonads and the rest occur in extragonadal tissues. ${ }^{3}$

Germ cell tumors are divided into seminomatous or non-seminomatous types. ${ }^{4}$ Non-seminomatous germ cell tumors (NSGCT) may be composed of embryonal carcinoma, teratoma, choriocarcinoma, or yolk sac tumors. Ninety percent of nonseminomatous tumors express either alphafetoprotein or human chorionic gonadotrophin $(\mathrm{hCG}){ }^{5}$ Intact hCG consists of two subunits. The $\alpha$ subunit is identical to the $\alpha$ subunit of the pituitary gonadotrophins and thyroid-stimulating hormone (TSH). The $\beta$ subunit is unique to $\mathrm{hCG}$, but strongly resembles the $\beta$ subunit of luteinizing hormone (LH). Beta-hCG levels are an important tool in the diagnosis and monitoring of treatment of NSGCT. Studies in animals and humans showed that hCG can activate the $\mathrm{TSH}$ receptor when present in excess and induce thyrotoxicosis. ${ }^{6,7}$ More than $40 \%$ of patients with beta-HCG in excess of $50,000 \mathrm{U} / \mathrm{L}$ have biochemical hyperthyroidism. ${ }^{8}$

We report a male patient presenting with metastatic extragonadal germ cell tumor EGCT) who developed thyrotoxicosis.

\section{hCG Induced Hyperthyroidism Due to a Metastatic Germ Cell Tumor} Hammad Hussain, M.D. ${ }^{1}$, Leigh M. Eck, M.D. ${ }^{2}$

${ }^{1}$ Quincy Medical Group, Quincy, IL ${ }^{2}$ University of Kansas Medical Center, Department of Medicine, Division of Endocrinology and Metabolism Kansas City, KS

\section{Case Report}

A 38-year-old male, without significant past medical history, presented with complaints of shortness of breath, hemoptysis, and night sweats of two-month duration. A chest x-ray showed diffuse pulmonary nodules confirmed on a subsequent chest computed tomography (CT) scan. In addition, an anterior mediastinal mass was identified on CT. A CT guided biopsy of the anterior mediastinal mass was performed. Based on the morphology and immune profile, this mass was classified as NSGCT with a predominant choriocarcinoma component. Staging revealed metastases to the brain, liver, spleen, and kidney. Testicular ultrasound did not reveal any masses, thus making the diagnosis of an extragonadal germ cell tumor (EGCT). A serum beta-hCG level was found to be greater than 200,000 U/L.

During this hospital admission in which chemotherapy was initiated, the patient developed persistent tachycardia and fever. In light of his known elevated beta-hCG level, a diagnosis of paraneoplastic hyperthyroidism with impending thyroid storm was entertained. Thyroid testing revealed a TSH of $0.071 \mathrm{mcu} / \mathrm{mL}(0.35-5.0)$, total T3 of $231 \mathrm{ng} / \mathrm{dL}(80-180)$, and a free thyroxine level of $3.0 \mathrm{ng} / \mathrm{dL}$ (0.6-1.6). Although the patient's thyrotoxicosis was suspected to be related to hCG induced hyperthyroidism, additional testing was undertaken to rule out an autoimmune etiology of thyrotoxicosis, 
including measurement of thyroid peroxidase antibodies (TPO) and thyroid stimulating immunoglobulins (TSI). Both TPO and TSI testing were normal thus ruling out Hashimoto's thyrotoxicosis and Grave's hyperthyroidism as potential etiologies. Radioactive iodine uptake and scanning was not pursued due to recent iodine loading with CT contrast material.

Due to symptomatic hyperthyroidism, the patient was initiated on anti-thyroid medication and propranolol. He received two cycles of a chemotherapeutic regimen including ifosfamide, paclitaxel, and cisplatin. Within days of initiating chemotherapy, his symptoms of thyrotoxicosis resolved and his free thyroxine normalized. His anti-thyroid medication and propranolol were rapidly tapered off. His beta-HCG level dropped to $148,047 \mathrm{U} / \mathrm{L}$ after the first cycle of chemotherapy and eventually to a nadir of $401 \mathrm{U} / \mathrm{L}$. Upon review of serial values of $\beta$ $\mathrm{HCG}$, free thyroxine, and TSH measurements, there was an obvious improvement in thyroid laboratory testing with decreasing $\beta$ hCG levels (see Figure 1). Unfortunately, the patient had further oncologic disease progression with poor response to additional cycles of cisplatin based chemotherapy. He expired within eight months of initial diagnosis.

\section{Discussion}

Paraneoplastic hyperthyroidism can occur in non-seminomatous germ cell tumors due to the choriocarcinoma component of these tumors which produces hCG. hCG has thyroid stimulating activity in animals as well as humans. ${ }^{9}$ In patients with NSGCT, the prevalence of hyperthyroidism in a large cohort study was $3.5 \%{ }^{10}$ Within this same cohort, the prevalence of hyperthyroidism increased to $50 \%$ in patients with high serum hCG levels at presentation $(>50,000 \mathrm{IU} / \mathrm{L}){ }^{10}$ Not all patients with significantly elevated hCG levels develop hyperthyroidism; this is thought to be related to the existence of hCG variants with different isoforms having different thyroid stimulating activity., 91 Another potential explanation for the disparate development of paraneoplastic hyperthyroidism may be the presence of polymorphisms of the TSH receptor gene, resulting in increased sensitivity of the TSH receptor to $\mathrm{hCG}^{12}$

hCG induced hyperthyroidism has been reported more commonly in women. ${ }^{13}$ Gestational transient thyrotoxicosis can be seen in women with high serum concentration of hCG during early pregnancy leading to hyperthyroidism characterized by elevated serum free thyroxine concentrations and low serum TSH concentrations. hCG related hyperthyroidism can be seen in women with gestational trophoblastic disease (GTD); the development of hyperthyroidism in this population is influenced largely by the level of hCG as well. ${ }^{14}$

Standardized recommendations for treatment of hCG induced hyperthyroidism in patients with testicular cancer do not exist. ${ }^{15}$ Patients with symptomatic hyperthyroidism are treated with $\beta$ adrenergic receptor antagonist therapy and/or antithyroid drugs. ${ }^{16}$ Anti-thyroid medications are an efficacious adjuvant treatment in $\mathrm{hCG}$ induced hyperthyroidism since hormone synthesis occurs within the thyroid gland. However, hyperthyroidism in hCG secreting malignant disease represents a paraneoplastic syndrome, therefore, the definitive treatment is treatment of the cancer.

\section{Conclusion}

hCG induced hyperthyroidism in GCTs can be overlooked as the signs and symptoms of hyperthyroidism may be attributed to the underlying malignancy and treatment of the same. In patients with NSGCT and hCG levels greater than 50,000, screening for thyroid dysfunction should be undertaken given the high prevalence of paraneoplastic 


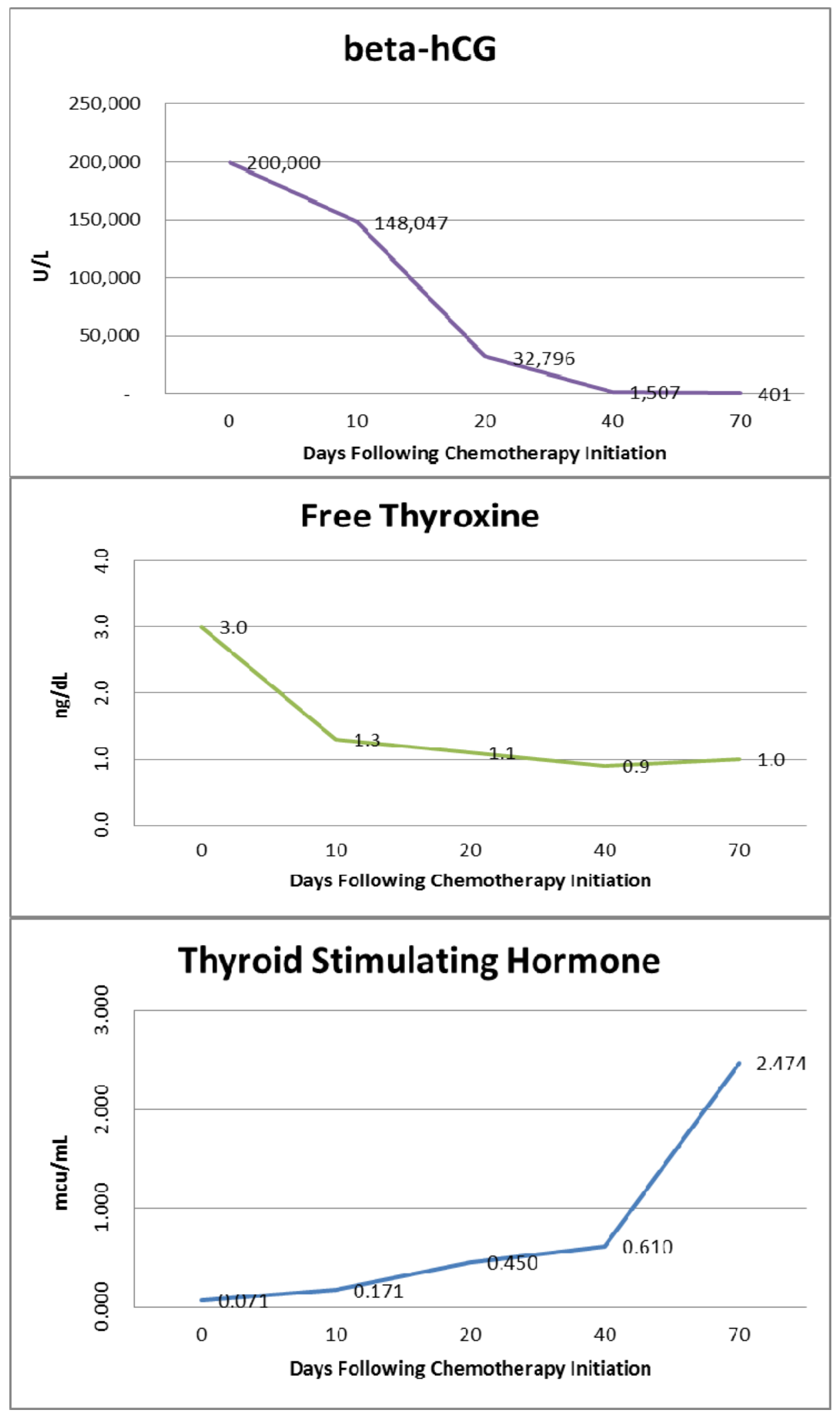

Figure 1. $\beta$-HCG, free thyroxine, and TSH measurements over time. 
hyperthyroidism in this cohort. Paraneoplastic hyperthyroidism can be managed with anti-thyroid medications as well as symptomatic therapy with $\beta$-adrenergic receptor antagonists. However, definitive treatment lies in treating the underlying malignancy.

\section{References}

1 American Cancer Society. Testicular Cancer. 2011. http://documents.cancer.org/ 121.00/121.00.pdf. Accessed: November 1, 2009.

${ }^{2}$ Schottenfeld D. Testicular cancer. In: Schottenfeld D, Fraumeni JF Jr. (eds.) Cancer Epidemiology and Prevention. New York, NY: Oxford University Press, 1996, pp. 1207-1219. ISBN: 0195149610.

3 Bosl GJ, Motzer RJ. Testicular germ-cell cancer. N Eng J Med 1997; 337(4):242253. PMID: 9227931.

${ }^{4}$ Mayordomo JI, Paz-Ares L, Rivera F, et al. Ovarian and extragonadal malignant germcell tumors in females: A single-institution experience with 43 patients. Ann Oncol 1994; 5(3):225-231. PMID: 7514435.

5 Milford-Ward A, Riches PG, Williams PE. (eds.) Protein Reference Unit Handbook of Clinical Immunochemistry. $7^{\text {th }}$ edition. Sheffield, UK: PRU Publications, 2001, pp. 193-194. ISBN: 0948722029.

${ }^{6}$ Voigt W, Maher G, Wolf HH, Schmoll HJ. Human chorionic gonadotropin-induced hyperthyroidism in germ cell cancer - a case presentation and review of the literature. Onkologie 2007; 30(6):330-334. PMID: 17585415.

7 Tilbrook LK, Slater J, Blainey AD. Testicular germ cell tumour presenting as thyrotoxicosis. Ann Clin Biochem 2004; 41(Pt 3):248-249. PMID: 15117443.

${ }^{8}$ Giralt SA, Dexeus F, Amato R, Sella A, Logothetis C. Hyperthyroidism in men with germ cell tumors and high levels of beta-human chorionic gonadotrophin. Cancer 1992； 69(5):1286-1290. PMID: 1371235.
${ }^{9}$ Hershman JM. Human chorionic gonadotrophin and the thyroid:

Hyperemesis gravidarum and trophoblastic tumors. Thyroid 1999; 9(7):653-657. PMID: 10447009.

${ }^{10}$ Oosting SF, de Haas EC, Links TP, et al. Prevalence of paraneoplastic hyperthyroidism in patients with metastatic nonseminomatous germ-cell tumors. Ann Oncol; 21(1):104-108. PMID: 19605510.

${ }^{11}$ Higgins HP, Hershman JM, Kenimer JG, Patillo RA, Bayley A, Walfish P. The thyrotoxicosis of hydatidiform mole. Ann Intern Med 1975; 83(3): 307-311.

${ }^{12}$ Rodien P, Jordan N, Lefévre A, et al. Abnormal stimulation of the thyrotropin receptor during gestation. Hum Reprod Update 2004; 10(2):95-105. PMID: 15073140 .

${ }^{13}$ Glinoer D, de Nayer P, Bourdoux P, et al. Regulation of maternal thyroid during pregnancy. J Clin Endocrinol Metab 1990; 71(2):276-287. PMID: 2116437.

${ }^{14}$ Walkington L, Webster J, Hancock BW, Everard J, Coleman RE. Hyperthyroidism and human chorionic gonadotrophin production in gestational trophoblastic disease. Br J Cancer 2011; 104(11):16651669. PMID: 21522146.

${ }^{15}$ Kellner O, Voigt W, Schneyer U, Dempke W, Schmoll HJ. HCG induced hyperthyroidism in germ cell cancer. Anticancer Res 2000; 20(6D):5135-5138. PMID: 11326684.

${ }^{16}$ Meister LH, Hauck PR, Graf H, Carvalho GA. Hyperthyroidism due to secretion of human chorionic gonadotropin in a patient with metastatic choriocarcinoma. Arq Bras Endocrinol Metabol 2005; 49(2):319-322. PMID: 16184264.

Keywords: hyperthyroidism, thyrotoxicosis, testicular neoplasms, germ cell tumor, human chorionic gonadotrophin 